\title{
PERFORMANCE OF PERVIOUS CONCRETE UNDER SHEAR AND BEARING STRENGTHS
}

\author{
1Yuva Pallavi, K., ${ }^{2}$ Giridhar, V. and Sashidhar ${ }^{3}$ C. \\ ${ }^{1}$ Ph.D Research Scholar, JNTUA, Anantapuramu,Andhra Pradesh, India \\ 2Professor in civil Engg Dept., KSRMCE, Kadapa, Andhra Pradesh, India \\ ${ }^{3}$ Professor in civil Engg Dept., JNTUACE, Anantapuramu, Andhra Pradesh, India
}

\section{ARTICLE INFO}

\section{Article History:}

Received $26^{\text {th }}$ March, 2021

Received in revised form

$11^{\text {th }}$ April, 2021

Accepted $03^{\text {rd }}$ May, 2021

Published online $26^{\text {th }}$ June, 2021

\section{Key Words:}

Black Marble Stone Waste Aggregate, Pervious concrete, Compressive strength, Shear strength, Bearing strength.

*Corresponding author:

\begin{abstract}
Pervious concrete is one of the materials with potential applications in the construction industry because it can help reduce environmental problems caused by conventional concrete, improve storm water management, and provide a low-impact development alternative. Pervious concrete has numerous advantages, including assisting with water filtering and lowering pollutants. The ability to reduce storm water runoff is the most important feature that attracts the attention of pervious concrete. The objective of the present investigation is to evaluate the properties of pervious concrete and compare them with normal concrete. On the other hand, the requirement for aggregate to produce concrete is high, while natural resources are reduced. An attempt was made to use Black Marble Stone Waste Aggregate in concrete by replacing natural aggregate at a ratio of 0,50 , and $100 \%$.To obtain the behavior of pervious concrete, compressive, shear and bearing strength are evaluated. A total of 54 specimens were casted and tested in this experimental work to study the behavior of concrete. To assess the shear and bearing strengths, a regression model was developed.
\end{abstract}

Copyright (C) 2021, Yuva Pallavi et al. This is an open access article distributed under the Creative Commons Attribution License, which permits unrestricted use, distribution, and reproduction in any medium, provided the original work is properly cited.

Citation: Yuva Pallavi, K., Giridhar, V. and Sashidhar, C. "Performance of Pervious Concrete under Shear and Bearing strengths", International Journal of Development Research, 11, (06), 47902-47905.

\section{INTRODUCTION}

Flooding is prevalent in metropolitan cities, especially where concrete is widely used. Concrete pavement is often an impermeable surface that prevents rainwater from percolating into the soil. This results in rain water runoff, which eventually leads to flooding. Climate change, increased urbanization, and inadequate storm water management systems will exacerbate the problem. One of the best-suited solutions to this problem is the use of pervious concrete pavement in surface runoff control. Pervious or porous concrete (PC) is concrete with a continuous void structure, containing no or a few fine aggregates. Pervious concrete is a composite material comprised mostly of cement, water, and coarse aggregates that has a substantially higher permeability than ordinary concrete. This type of concrete offers the benefits of reducing runoff volume and possibly improving water quality in ground water recharge. Pervious concrete is an environmentally-friendly building material and the EPA (Environmental Protection Agency) has identified it as a Best
Management Practice (BMP) for storm water management. The benefits of storm water management, which contributes to sustainable development, have increased awareness of pervious concrete. Its application has been limited to parking lots, driveways, sidewalks, and low-traffic roads. Various sectors produce a great deal of waste, which has a huge impact on the environment and natural resources. To avoid contamination and preserve environmental resources, it is critical to limit this waste. In the construction field, the utilization of waste materials as a coarse aggregate replacement has become a hot topic. The polishing industry generates black marble stone waste, which is deposited in and around the industries. The utilization of this waste in mortar or concrete helps to reduce aggregate shortages while also preventing pollution. The scope of this study is focused on the substitution of aggregate with Black Marble Stone Waste Aggregate in various proportions. Black stone marble waste is one of the materials that can be used in concrete because it has all of the required properties. 


\section{LITERATURE SURVEY}

In this section, past literature works have been presented to know the status in the area of pervious concrete. Obla (2010) studied that the compressive strength and permeability of pervious concrete are the most important aspects. To provide sufficient strength and permeability, pervious concrete mixtures are typically designed to contain a void percentage of $20 \%$. Jigar J. Anghan et.al (2018) did the experimental work on concrete to estimate the pervious nature. Baoshan Huang et al. (2009) evaluated the effects of latex, natural sand and fiber on the pervious concrete. Different tests such as permeability test, compressive strength test, split tensile strength test were conducted. Aoki et al. (2012) conducted an experimental investigation on pervious concrete by replacing cement with fly ash up to $50 \%$. To improve the mechanical qualities, fine aggregate is included up to $10 \%$. According to the findings, replacing $50 \%$ of Portland cement with fly ash reduces compressive strength by $40 \%$ while also lowering drying shrinkage. Schaefer VR et al [10], developed the mix designs for pervious concrete for cold weather conditions. From the literature, a little work has been done on shear and bearing characteristics of pervious concrete by using the alternate materials. Hence, it is planned to know performance of Black Marble Stone Waste Aggregate in the pervious concrete.

OBJECTIVES OF THE EXPERIMENTAL WORK: The main aim of the present work is to evaluate the strength characteristics of pervious concrete. Pervious concrete is prepared with cement and coarse aggregate. In the concrete mix, the naturalaggregate is replaced by the Black Marble Stone Waste Aggregate in the proportions of 0, 50 and $100 \%$. The mix design was done for normal concrete. The following objectives are set for the experimental work.

- To study the strength characteristics of compression, shear and bearing strengths of pervious concrete.

- The obtained results are compared with normal concrete.

\section{MATERIALS AND EXPERIMENTAL MODULE}

For the present experimental work the following materialswere used.

Cement: OPC 53 grade cement was used. The specific gravity is 3.15 .

Natural Aggregate: $20 \mathrm{~mm}$ size aggregate is used ascoarse aggregate.

Black Marble Stone Waste Aggregate: Crushed Black Marble stone waste aggregate with a maximum size of $20 \mathrm{~mm}$ is used. The specific gravity is 2.75 .

Water: portable water was used.

Casting and Curing: Standard cubes $(150 \times 150 \times 150 \mathrm{~mm})$ and cylinders $(150 \mathrm{~mm}$ diax $300 \mathrm{~mm}$ height) are casted and the specimens are cured in water tank for a period of 28 days. Total 36 cubes and 18 cylinders are casted. Compressive strength test is conducted on cubes. Shear strength test is conducted on cylinders. Bearing strength test is conducted on cubes. The testing of specimens is shown in Fig. 1, Fig 2 and Fig 3.

\section{RESULTS AND DISCUSSION}

Compressive Strength: The cube compressive strength results are presented in Tablel and the graphical representation is shown in Fig 4. It is observed that, as the replacement of BMSWA is increased the cube compressive strengths are reduced. For $100 \%$ of natural aggregate the compressive strength of normal concrete is $28.44 \mathrm{Mpa}$. For $50 \%$ of natural aggregate the compressive strength of normal concrete is $23.11 \mathrm{MPa}$ and for $100 \%$ of BMSWA the compressive strength is 18.11 . The natural aggregate is replaced with BMSWA in the proportions of $50 \%$ and $100 \%$ and the compressive strengths are reduced by $18.74 \%$ and $36.32 \%$ respectively.

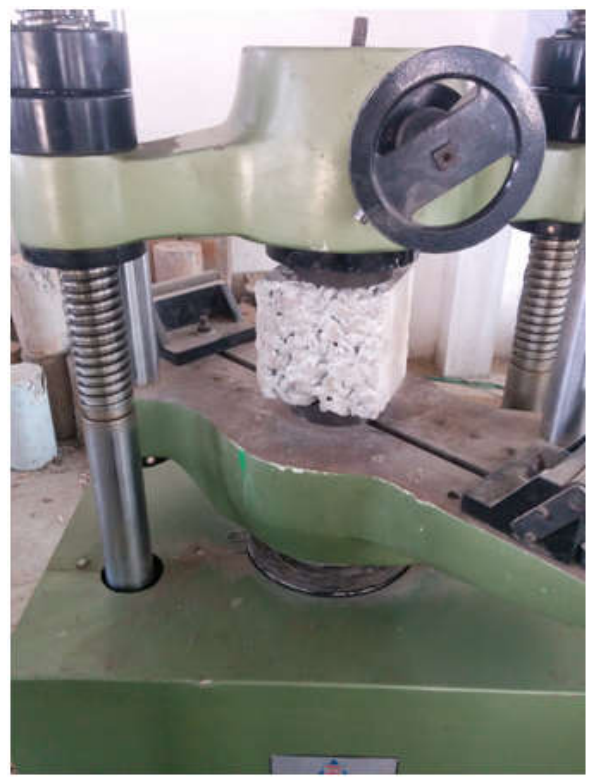

Fig.1. Compressive Strength Test

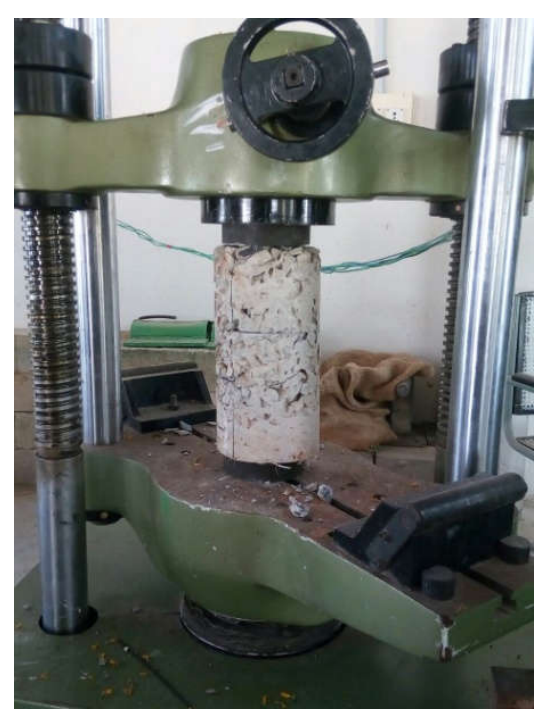

Fig. 2. Shear Strength Test

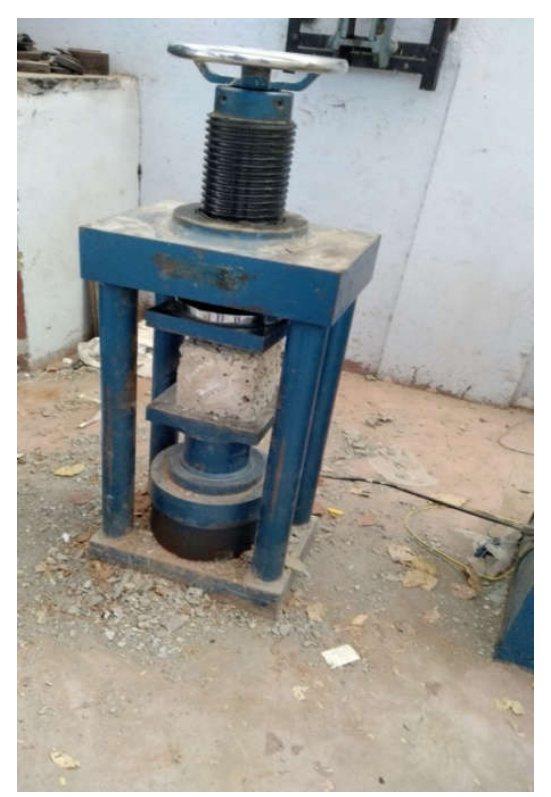

Fig. 3. Bearing Strength Test 
For $100 \%$ of natural aggregate the compressive strength of Pervious concrete is $4.69 \mathrm{Mpa}$. For $50 \%$ of natural aggregate the compressive strength of pervious concrete is $2.86 \mathrm{Mpa}$. For $100 \%$ of BMSWA the compressive strength is $0.93 \mathrm{Mpa}$. From the results it is also noticed that, strengths are decreased as the percentage replacement of BMSWA increased. strengths are reduced. The maximum decrease in the bearing is noticed for $100 \%$ BMSWA mix.

Relation between Shear Strength and Cube Compressive Strength: A model between shear and compressive strengths for 28 days is developed.

Table 1. Test Results

\begin{tabular}{ccccccc}
\hline $\begin{array}{c}\text { S1.N } \\
\text { o }\end{array}$ & $\begin{array}{c}\text { Replacement of } \\
\text { Aggregate }\end{array}$ & \multicolumn{2}{c}{$\begin{array}{c}\text { Cube Compressive } \\
\text { strength (MPa) }\end{array}$} & \multicolumn{2}{c}{ Shear strength (MPa) } & Bearing strength (MPa) \\
\cline { 2 - 6 } & & NC & PC & NC & PC & NC \\
\hline 1 & 0 & 28.44 & 4.69 & 3.85 & 1.48 & 47.5 \\
2 & 50 & 23.11 & 2.86 & 3.46 & 1.15 & 38.6 \\
3 & 100 & 18.11 & 0.93 & 3.06 & 0.65 & 3.34 \\
\hline
\end{tabular}

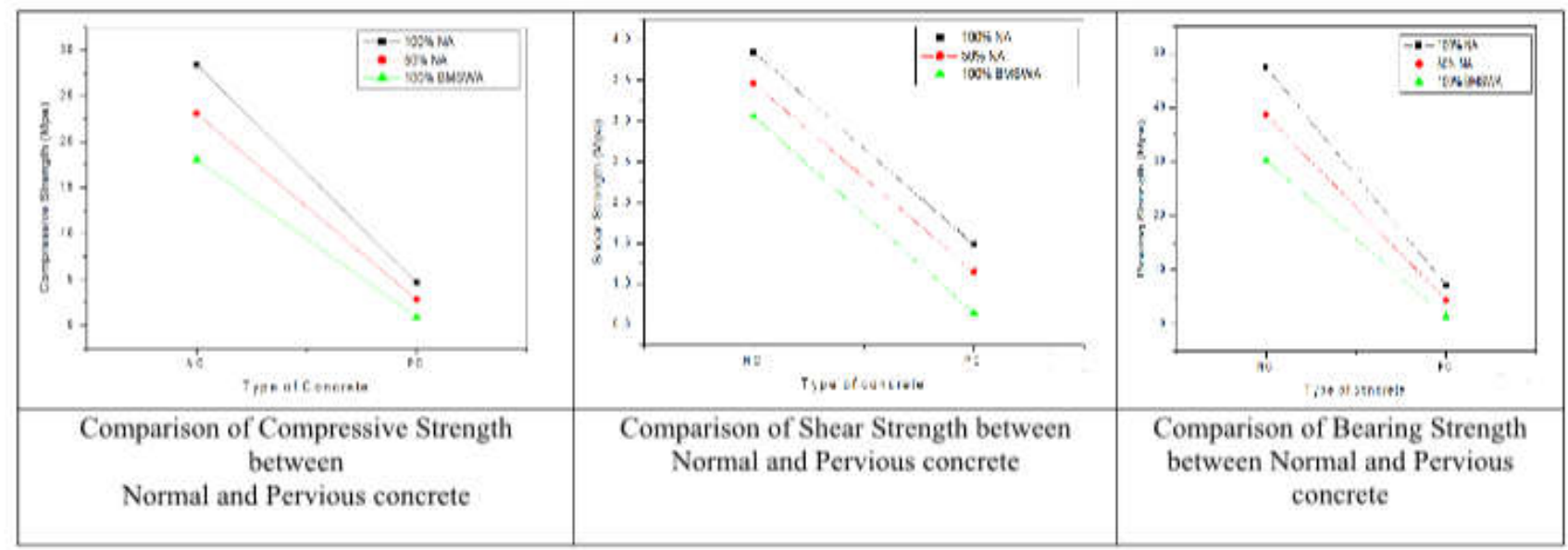

Fig. 4. Comparison of different strengths between Normal Concrete and Pervious Concrete

Table 2. Performance of the regression models for Shear and Bearing Strength for 28 days

\begin{tabular}{|c|c|c|c|c|c|c|c|c|c|c|c|c|}
\hline \multirow{3}{*}{$\begin{array}{l}\text { Replacement } \\
\text { of Aggregate }\end{array}$} & \multicolumn{6}{|c|}{ Shear strength $(\mathrm{MPa})$} & \multicolumn{6}{|c|}{ Bearing strength $(\mathrm{MPa})$} \\
\hline & \multicolumn{3}{|c|}{ Normal concrete } & \multicolumn{3}{|c|}{ Pervious concrete } & \multicolumn{3}{|c|}{ Normal concrete } & \multicolumn{3}{|c|}{ Pervious concrete } \\
\hline & $\begin{array}{l}\text { Ultimate } \\
\text { Value } \\
3.85\end{array}$ & $\begin{array}{l}\text { Value by } \\
\text { Regression } \\
3.92\end{array}$ & $\begin{array}{l}\text { Ratio } \\
0.98 \\
\end{array}$ & $\begin{array}{l}\text { Ultimate } \\
\text { Value } \\
1.48\end{array}$ & $\begin{array}{l}\text { Value by } \\
\text { Regression } \\
1.59\end{array}$ & $\begin{array}{l}\text { Ratio } \\
0.92 \\
\end{array}$ & $\begin{array}{l}\text { Ultimate } \\
\text { Value } \\
47.5\end{array}$ & $\begin{array}{l}\text { Value by } \\
\text { Regression } \\
47.97\end{array}$ & $\begin{array}{l}\text { Ratio } \\
0.99\end{array}$ & $\begin{array}{l}\text { Ultimate } \\
\text { Value } \\
7.13\end{array}$ & $\begin{array}{l}\text { Value by } \\
\text { Regression } \\
7.91\end{array}$ & Ratio \\
\hline 50 & 3.46 & 3.54 & 0.97 & 1.15 & 1.24 & 0.92 & 38.6 & 38.98 & 0.99 & 4.34 & 4.82 & 0.89 \\
\hline 100 & 3.06 & 3.13 & 0.97 & 0.65 & 0.70 & 0.91 & 30.24 & 30.55 & 0.989 & 1.41 & 1.56 & 0.89 \\
\hline
\end{tabular}

Shear Strength: The results of shear strength are presented in Table1 and the graphical representation is shown in Fig 4. For $100 \%$ of natural aggregate the shear strength of normal concrete is $3.85 \mathrm{Mpa}$. For $50 \%$ of natural aggregate the shear strength of normal concrete is $3.46 \mathrm{MPa}$ and for $100 \%$ of BMSWA the shear shear strength is 3.06 $\mathrm{MPa}$. The natural aggregate is replaced with BMSWA in the proportions of $50 \%$ and $100 \%$ and the shear strengths are reduced by $10.12 \%$ and $20.51 \%$ respectively. In case of pervious concrete of $100 \%$ of natural aggregate, $50 \%$ of natural aggregate and $100 \%$ of BMSWA the shear strengths are $1.48 \mathrm{Mpa}, 1.15 \mathrm{Mpa}$ and $0.65 \mathrm{Mpa}$ respectively. From results, it is observed that as the replacement of BMSWA is increased the shear strengths are reduced. The maximum decrease in the shear strength is noticed for $100 \%$ BMSWA mix.

Bearing Strength: The Bearing strength results are presented in Table1 and the graphical representation is shown in Fig 4. For the normal concrete of $100 \%$ of natural aggregate, $50 \%$ of natural aggregate and $100 \%$ of BMSWA the bearing strengths are $47.5 \mathrm{Mpa}$, $38.6 \mathrm{Mpa}$ and $30.24 \mathrm{Mpa}$ respectively. The natural aggregate is replaced with BMSWA in the proportions of $50 \%$ and $100 \%$ and the bearing strengths are reduced by $18.73 \%$ and $36.33 \%$ respectively. In case of pervious concrete of $100 \%$ of natural aggregate, $50 \%$ of natural aggregate and $100 \%$ of BMSWA the bearing strengths are 7.13 Mpa, 4.34 Mpa and 1.41 Mpa respectively. From results, it is observed that as the replacement of BMSWA is increased the bearing
A regression model was developed by the method of least squares and presented below. The relationship equation is given as

$\mathrm{f}_{\mathrm{sh} 28}=0.737 \sqrt{\left(\mathrm{f}_{\mathrm{c} 28}\right)}$

$\mathrm{f}_{\text {sh28 }}=28$ days shear strength of concrete in MPa

$\mathrm{f}_{\mathrm{c} 28}=28$ days compressive strength of concrete in MPa The performance of the regression model is tested for the experimental results and shown in Table 2. It is noticed that the ratio between experimental to regression model is varied from 0.91 to 0.98 and the average ratio between the strengths is observed as 0.95 .

Relation between bearing Strength and Cube Compressive Strength: A model between bearing and compressive strengths for 28 days is developed. A regression model was developed by the method of least squares and presented below. The relationship equation is given as

$\mathrm{f}_{\mathrm{b} 28}=1.671\left(\mathrm{f}_{\mathrm{c} 28}\right)$

$\mathrm{f}_{\mathrm{b} 28}=28$ days bearing strength of concrete in MPa

$\mathrm{f}_{\mathrm{c} 28}=28$ days compressive strength of concrete in $\mathrm{MPa}$ 
The performance of the regression model is tested for the experimental results and shown in Table 2. It is noticed that the ratio between experimental to regression model is varied from 0.89 to 0.99 and the average ratio between the strengths is observed as 0.94 .

\section{CONCLUSION}

- As the percentage of BMSWA increases, the compressive strength is decreased by $18.74 \%$ and $36.32 \%$ for 50 and 100 $\%$ of replacement.

- $\quad$ The shear strength decreased about $10.12 \%$ to $20.51 \%$ for the 50 and $100 \%$ of BMSWA replacement when compared as the natural aggregate

- $\quad$ The bearing strength of concrete decreased about $18.73 \%$ and $36.34 \%$ for 50 and $100 \%$ of BMSWA replacement.

\section{REFERENCES}

American Concrete Institute (ACI) Committee 522 "Report on pervious concrete", Technical committee document, ACI 522R10,(2006) American Concrete Institute.

Aoki, Y, Sri Ravindrarajah, R \& Khabbaz, H 2012, "Properties of pervious concrete containing fly ash", Road Materials and Pavement Design, vol. 13, no. 1, pp. 1-11.

Baoshan Huang, Hao Wu, Xiang Shu and Edwin G, Burdette, 2009. "Laboratory evaluation of permeability and strength of polymermodified pervious concrete". Construction and Building Materials 24: 818-823.
Cian and Y. Zhuge 2010. Optimum mix design of enhanced permeable concrete-An experimental investigation". Construction and Building Materials 24: 2664-2671.

Dang Hanh Nguyen, Mohamed Boutouil, Nassim Sebaibi, Fabienne Baraud, Lydia Leleyter, "Durability of pervious concrete using crushed seashells", "Construction Building Materials", page no 137-150, 2017

Jigar J. Anghan , Harsh V. Gevariya, Jugal Mistry, “A Review Paper on Permeable Concrete as A Road Pavement for a Storm Water", "International Journal for Scientific Research \& Development" Vol. 6, Issue 02, 2018 ISSN (online): 2321-0613

Kamel K. Alzboon, Khalid N. Mahasneh, Effect of Using Stone Cutting Waste on the Compression Strength and Slump Characteristics of Concrete, International Journal of Environmental, Chemical, Ecological, Geological and Geophysical Engineering Vol. 3, No. 3, 2009, pp. 83-88.

Karthick H Obla 2010, "Pervious concrete- An overview", The Indian Concrete Journal, vol. 84, pp. 9-18.

Memery Serifou, Z.M. Sbrtai, S. Yotte, M.O. Boffoue, E. Emeruwa, F. Bos, 2013. "A Study of concrete made with fine and coarse aggregates recycled from fresh concrete waste", "Hindawi Publishing Corporation Journal of construction Engineering", Vol. 5, pages 1-5, Article ID 317182.

Schaefer VR, Wang K, Suleiman MT and Kevern JT. 2006. "Mix design development for pervious concrete in cold weather climates". Final report. National concrete pavement technology centre, Iowa State University. 